\title{
СТРУКТУРНІ ЗМІНИ У ФІБРОЇНОВОМУ ВОЛОКНІ ПІД ДІЕЮ ЛУЖНОГО РОЗЧИНУ
}

\author{
Л.А. БУЛАВІН, Ю.Ф. ЗАБАШТА, А.В. КАСПРОВА, С.П. СЕНЧУРОВ, \\ O.C. CBEЧНIKOBA
}

Київський національний університет ім. Тараса Шевченка, фізичний факультет

(64, Володимирсъка, Київ, МСП 01601; e-mail: zabashta@mail.univ. kiev.ua)

\begin{abstract}
Проведено порівняльне дослідження акустичних властивостей фіброїнових волокон, оброблених і необроблених лужним розчином. Отримано залежності швидкості звуку від статичного напруження, розтягуючого волокно. За цією залежністю розраховано значення модулів пружності другого та третього порядків. На основі одержаних значень зроблено висновки про зміни структури, що відбуваються у фіброїновому волокні під час обробки його лужним розчином, а саме: встановлено, що обробка приводить до появи дефектів типу порожнин у невпорядкованих областях та орієнтації ланцюгів в цих областях уздовж осі волокна.
\end{abstract}

\section{1. Вступ}

Фіброїнові волокна - шовк, як відомо [1,2], утворюються внаслідок життєдіяльності шовкопряда, наприклад, Bombyxmori. Секрет його залоз містить водний розчин білка фіброїна в суміші з іншим білком - серицином, який відіграє роль мастила та клею. Шовкопряд, приклеївши краплю секрету до стороннього предмета, витягує увесь вміст залози у вигляді рідкої струмини, яка, твердіючи на повітрі, перетворюється на волокно. Волокна згортаються шовкопрядом у кокон, який зберігає свою цілісність завдяки склеюванню волокон серицином.

У промисловості волокна відокремлюють від серицина, обробляючи кокони водним розчином $\mathrm{NaOH}$.

Мета даної роботи - виявити структурні зміни у фіброїновому волокні, спричинені дією згаданого розчину.

Загальновідомо, що вислів "система має структуру" вживається, коли дану систему можна подати як сукупність окремих частин. Останні носять назву стру- ктурних елементів. Систему можна розділити на частини, спираючись на розмір вибраного структурного елемента. У цьому випадку говорять про різні структурні рівні системи.

Виходячи із сучасних поглядів [3] на структуру фіброїнових волокон можна говорити про існування у них чотирьох структурних рівнів:

1) макроскопічного, для якого структурний елемент домірний до діаметра волокна;

2) клітинного, структурним елементом якого є клітина;

3) фібрилярного, де структурним елементом виступає фібрила;

4) атомного.

$\mathrm{У}$ даній роботі вивчення структури проводиться на фібрилярному рівні. Відповідна структурна модель зображена на рис. 1.

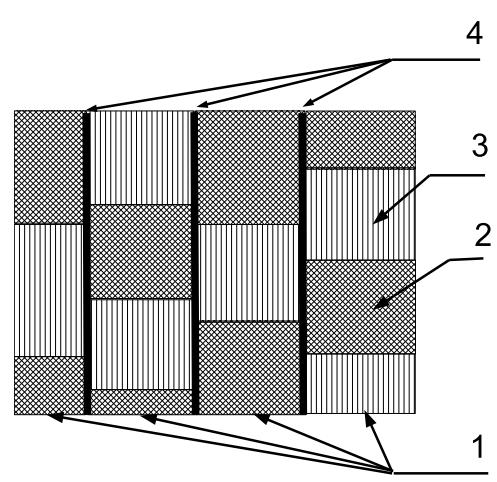

Рис. 1. Фібрилярний структурний рівень волокна: 1 - фібрили, 2 - невпорядковані внутрішньофібрилярні області, 3 - впорядковані внутрішньофібрилярні області, 4 - невпорядковані міжфібрилярні області 
Як вже згадувалось, структурним елементом в даному випадку є фібрила. Це кластер ланцюгів, що має циліндричну форму. Вісь такого циліндра паралельна осі волокна. Діаметр згаданого циліндра становить 7,5-8 нм.

Фібрили відділені одна від одної невпорядкованими міжфібрилярними областями. Уздовж фібрили чередуються одна з одною впорядковані та невпорядковані внутрішньофібрилярні області.

Впорядкована область являє собою кристалічну гратку, утворену фіброїновими ланцюгами, осі яких паралельні осі фібрили. Ці ланцюги мають конфігурацію плоского зигзага.

Тепер, коли задекларовано модель структури волокна, з якою ми будемо працювати, мету роботи можна сформулювати більш конкретно: у даній статті ми намагатимемось визначити на фібрилярному рівні зміни структури, що відбуваються з волокном внаслідок дії лужного розчину.

\section{2. Методика експерименту}

За допомогою акустичного інтерферометра проводилось вивчення структури фіброїнового волокна. Вимірювалась швидкість звуку $c$ у фіброїнових волокнах, на які діяло статичне розтягуюче напруження $\sigma$. Згаданий метод традиційно використовується при дослідженні акустичних властивостей волокон. Його опис можна знайти, наприклад, у роботі [4] та ін.

Власне кажучи, мета, яку ми ставили перед собою, виконуючи експеримент, полягала у знаходженні залежності модуля пружності волокна $E$ від напруження $\sigma$. Саме по характеру цієї залежності ми намагатимемось робити висновки щодо структури фіброїнового волокна.

Модуль пружності, як відомо [5], розраховується за формулою

$E=\rho c^{2}$,

де $\rho$ - густина. Тож виміряні в експерименті швидкості звуку с легко перераховуються в значення модуля пружності $E$.

Відомо також [5], що при температурах порядку 300-400 K в полімерах "розморожуються" релаксаційні процеси. Їх протікання спричиняе певні зміни у структурі, що накладаються на структурні зміни, викликані дією лужного розчину. Оскільки в даній статті ми ставимо перед собою задачу визначити лише ті структурні зміни, що виникли завдяки обробці волокна лужним розчином, необхідно виключити із розгляду вплив релаксаційних процесів на структуру фіброїнового волокна. Задля цього виміри проводились при температурі $T=153 \mathrm{~K}$.

\section{3. Характеристика досліджуваних зразків}

Вже з самого формулювання задачі очевидно, що для їі розв'язку необхідно порівняти між собою експериментальні дані для волокон, оброблених та необроблених лужним розчином. Але як одержати у нашому випадку необроблені зразки? Адже від шовкопряда маємо лише кокон, в якому волокна, склеєні серицином. Для того щоб отримати із кокона зразок волокна для дослідження, ми обов'язково мусимо обробити кокон, а значить, і волокна, лужним розчином.

Оскільки каменем спотикання виявився кокон, стало зрозумілим, що необроблені волокна можна отримати, лише змінивши "умови роботи" шовкопряда, не даючи йому змоги, утворити із волокна кокон. Цього було досягнуто силовим витягуванням струмини секрету безпосередньо із залоз шовкопряда. Волокна, отримані таким способом, й називатимемо необробленими. Цю групу зразків далі позначатимемо літерою А.

Досліджувалось ще дві групи (В і C) зразків. Зразки В було отримано із зразків А обробкою останніх лужним розчином. Зразки С - це шовкові волокна, одержані за традиційною технологією - обробкою лужним розчином коконів.

\section{4. Результати експерименту та їх обговорення}

Як відомо, для більшості біологічних матеріалів залежність між напруженням $\sigma$ та деформацією $\varepsilon \in$ нелінійною. Відповідно модуль пружності $E$ виявляється залежним від напруження $\sigma$. Цей факт підтверджується нашими експериментальними даними. На рис. 2 наведено залежності від статичного напруження модулів пружності, розрахованих за формулою (1) із запозиченим із літератури [6] значенням густини. Як видно із рис. 2, згадані залежності можна вважати лінійними, записавши для них вираз

$E=E_{0}+B \sigma$

Оскільки $\sigma=E_{0} \varepsilon[5]$, де $\varepsilon$ - розтягуюча деформація, то попередній вираз можна переписати у вигляді формули

$E=E_{0}+E_{1} \varepsilon$ 
в якій прийнято позначення

$E_{1}=B E_{0}$.

Як видно із виразів (2), (3), з точки зору реології фіброїн відноситься до класу нелінійно пружних середовищ (ознаки цього класу див., наприклад, у роботі [7] та ін.). Лінійні деформаційні властивості таких середовищ прийнято характеризувати модулем другого порядку $E_{0}$, нелінійні - модулем третього порядку $E_{1}$.

В даній статті ми намагатимемось по значенням модулів $E_{0}$ і $E_{1}$ робити висновки щодо структури на фібрилярному рівні. Зрозуміло, що виконати цю задачу можна лише тоді, коли відомо, який внесок у значення модуля дає та чи інша структурна область.

Позначимо через $E_{F}$ модуль фібрили як цілого, через $E_{C}, E_{P}, E_{S}$ - модулі впорядкованої, міжфібрилярної невпорядкованої та внутрішньофібрилярної областей, через $n_{C}, n_{P}, n_{S}$ - об'ємні концентрації останніх.

Апріорі можна стверджувати, що модуль міжфібрилярної невпорядкованої області, де вже за визначенням ступінь орієнтації ланцюгів незначний, суттєво менший за модуль фібрили, в якій містяться, впорядковані області з ланцюгами, орієнтованими уздовж осі фібрили, тобто:

$E_{p} \ll E_{F}$.

Прийнято вважати [8], що міжфібрилярні невпорядковані області виникають як перехідні шари між фібрилами. Вже із самого визначення перехідного шару випливає, що його товщина мусить бути суттєво меншою за розмір області, до якої цей шар прилягає. У нашому випадку це означає існування нерівності

$n_{p} \ll n_{C}+n_{S}$.

Існування малих параметрів $\alpha=\frac{E_{P}}{E_{F}}$ i $\beta=\frac{n_{P}}{n_{C}+n_{S}}$ дозволяє записати для модуля $E$ вираз

$E=E^{0}+E^{1}+\ldots$,

де $E^{0}, E^{1}$ і т. д. - члени нульового, першого і т. д. порядку малості по малих параметрах $\alpha$ i $\beta$.

Надалі обмежимось нульовим наближенням, записавши вираз

$E \approx E^{0}$

Нульове наближення по параметрах $\alpha$ і $\beta$ означає, що у цьому наближенні вважаються справедливими рівності

$n_{P} \approx 0$

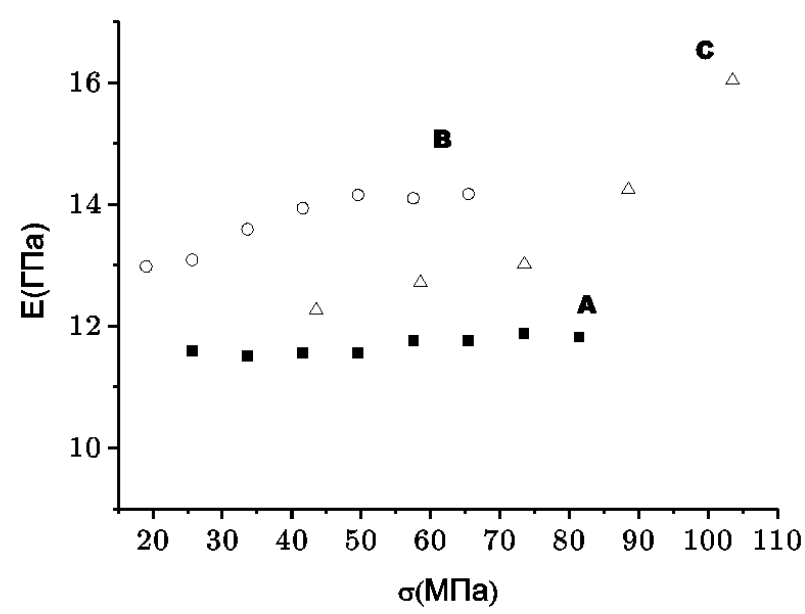

Рис. 2. Залежність модуля пружності від навантаження $E(\varepsilon)$ для зразків: А - фіброїнове волокно, отримане безпосередньо із залоз шовкопряда, В - фіброїнове волокно, отримане із залоз шовкопряда і оброблене лужним розчином, C - фіброїнове волокно, отримане з кокона шовкопряда

$E_{P} \approx 0$

3 рівностей (9), (10) випливає, що в даному наближенні ми ігноруємо наявність у структурі міжфібрилярних невпорядкованих областей. Іншими словами, взаємодія між фібрилами у структурній моделі нульового наближення відсутня - в цьому наближенні фібрили під дією зовнішньої сили деформуються незалежно одна від одної. За таких припущень увесь об'єм волокна зайнято фібрилами й, відповідно, для модуля пружності $E$ волокна виявляється справедливою наближена рівність

$E=E_{F}$

Фібрила являє собою сукупність послідовно з'єднаних впорядкованих й невпорядкованих областей. Послідовне з'єднання означає [5], що піддатливість $\frac{1}{E_{F}}$ фібрили є сумою піддатливостей окремих областей, а саме:

$\frac{1}{E_{F}}=\frac{n_{C}}{E_{C}}+\frac{n_{S}}{E_{S}}$.

Як наслідок рівності (9) записуємо вираз

$n_{C}+n_{S}=1$.

Відповідно для модуля пружності волокна маємо формулу

$E=\frac{E_{S} E_{C}}{\left(1-n_{C}\right) E_{C}+n_{C} E_{S}}$. 
Записавши вирази

$E_{C}=E_{0}+E_{0 C} \varepsilon$

$E_{S}=E_{0}+E_{0 S} \varepsilon$

введемо у розгляд модулі другого та третього порядку для впорядкованих $\left(E_{0 C}\right.$ і $\left.E_{1 C}\right)$ й невпорядкованих областей $\left(E_{0 S}\right.$ і $\left.E_{1 S}\right)$. Щільне пакування ланок у впорядкованих областях створює значні перешкоди для розвитку в них нелінійних деформацій на відміну від невпорядкованих областей, де наявність вільного об'єму, а значить, і менша інтенсивність взаємодії між ланцюгами, сприяє виникненню нелінійних деформацій. Ці обставини дозволяють стверджувати, що спостережена в експерименті нелінійність деформацій пов'язана виключно із невпорядкованими областями, тобто:

$E_{1 C}=0$.

Підставляючи рівності (3), (15)-(17) у формулу (14), розкладаючи праву і ліву частини отриманого рівняння у ряд по степенях $\varepsilon$ і обмежуючись членами першої степені, отримуємо

$E_{0}=\frac{E_{0 S} E_{0 C}}{\left(1-n_{C}\right) E_{0 C}+n_{C} E_{0 S}}$,

$E_{1}=E_{1 S} \frac{E_{0 C}}{\left(1-n_{C}\right) E_{0 C}+n_{C} E_{0 S}} \times$

$\times\left(1-\frac{n_{C} E_{0 S}}{\left(1-n_{C}\right) E_{0 C}+n_{C} E_{0 S}}\right)$.

Використовуючи формули (18), (19), маємо змогу за експериментальними значеннями модулів волокна $E_{0}$ i $E_{1}$ визначити модулі $E_{0 S}$ і $E_{1 S}$ невпорядкованих областей за умови, що величини $n_{C}$ та $E_{C}$ відомі.

Значення $E_{C}=23$ ГПа запозичимо із роботи [9], де воно було визначено рентгенографічним методом по зміщенню рефлексів під дією зовнішньої сили.

Концентрацію $n_{C}$ розрахуємо виходячи 3 таких міркувань. Як відомо [1], первинна структура фіброїнових ланцюгів може містити 18 амінокислотних залишків. Прийнято вважати [10], шо тільки чотири із них - Глі, Ала, Сер та Тір - входять до складу ділянок ланцюгів, що утворюють впорядковані області. Виходячи із цього твердження, будемо розглядати концентрацію $n_{C}$, як відносний об'єм, зайнятий згаданими чотирма амінокислотними залишками. Запозичивши із роботи [10] дані про відносний об'єм амінокислотних залишків, записуємо $n_{C}=0,53$. Обчислені за формулами (18), (19) значення модулів $E_{0 S}$ та $E_{1 S}$ наведено в таблиці.

Проаналізуємо дані, наведені в таблиці. Почнемо 3 величини $E_{0 S}$ - модуля другого порядку невпорядкованих областей. Як видно із значень таблиці, модуль $E_{0 S}$ для зразків C суттєво менший за той же модуль для зразків А. Зменшення модуля, як правило, свідчить про зростання дефектності структури. Тож можна стверджувати, що обробка фіброїнових волокон лужним розчином приводить до збільшення кількості дефектів у невпорядкованих областях.

Щодо характеру цих дефектів можна висловити такі міркування: під час обробки фіброїнового волокна лужним розчином молекули $\mathrm{NaOH}$ разом із молекулами води проникають у невпорядковані області, розміщуючись між ланцюгами фіброїну. Після видалення цих молекул у структурі волокна залишаються пустоти. На нашу думку, ці пустоти і є тими дефектами, що спричиняють зменшення модуля $E_{0 S}$ після обробки волокна лужним розчином.

Такому висновку, здавалося б, суперечить та обставина, що модуль $E_{0 S}$ для зразків типу В більший за відповідний модуль зразків А. Зразки типу В отримані обробкою лужним розчином зразків А. Однак, різниця між значеннями модуля $E_{0 S}$ для зразків А i В практично знаходяться в межах похибки, яка $€$ результатом, як експериментальних вимірювань, так і тих наближень, які були прийняті при обчисленні $E_{0 S}$. Отож, можна вважати, що тенденція у даному випадку зберігається, тобто під час обробки лужним розчином структура невпорядкованих областей можливо також стає дефектною. Однак, ці зміни залишаються в межах похибки.

Що стосується модулів третього порядку $E_{1 S}$ та $E_{1 C}$, то головним експериментальним фактом, на нашу думку, є та обставина, що для усіх трьох зразків модулі третього порядку мають додатний знак. Модулі третього порядку для волокон досліджувались у роботі [4], де було показано, що додатний знак модуля третього порядку відповідає дії нецентральних

Т а б л и ц я. Деформаційні характеристики невпорядкованих областей фіброїнових волокон

\begin{tabular}{c|c|c}
\hline $\begin{array}{c}\text { Тип } \\
\text { волокна }\end{array}$ & $\begin{array}{c}\text { Модуль } \\
\text { другого порядку }\end{array}$ & $\begin{array}{c}\text { Модуль } \\
\text { третього порядку }\end{array}$ \\
\hline А & 7,22 & 0,06 \\
В & 8,29 & 0,33 \\
C & 4,52 & 1,31 \\
\hline
\end{tabular}


сил. У свою чергу, переважання цього типу сил є наслідком орієнтації ланцюгів у напрямку осі волокна. Таким чином, грунтуючись на отриманому нами результаті можна стверджувати, що ланцюги фіброїну у невпорядкованих областях для усіх трьох зразків орієнтовані переважно вздовж осі волокна.

У невпорядкованих областях розташовуються ділянки ланцюгів, які неспроможні утворити гратку. Відомо, що у впорядкованих областях фіброїнові ланцюги мають форму плоского зигзага [11]. Виявлений нами факт існування орієнтації ланцюгів у невпорядкованих областях свідчить про те, що у цих областях ланцюги мають конфігурацію, близьку до плоского зигзага. Як відомо [12], конфігурацію білкових ланцюгів можна розглядати, як послідовність віртуальних зв'язків, що з'єднують між собою атоми вуглецю, які не входять до складу пептидних груп. Відповідно до цього, відхилення конфігурації пептидного ланцюга від плоского зигзага можна описувати в термінах кутів повороту віртуальних зв'язків один відносно одного (у плоскому зигзазі усі віртуальні зв'язки лежать в одній площині). Таким чином, неможливість певного амінокислотного залишку (такими залишками вважають гліцин, аланін, серин, тирозин, аспірагин, аргінін, гістадин, глютамін, лізин, валін, лейцин, фенілаланіл, пролін, треонін, метионін, цистеїн, триптофан та ізолейцин) розташуватись у площині зигзага приводить до повороту відповідного віртуального зв'язку, або, що те саме, виходу цього зв'язку із площини зигзага.

Модуль третього порядку при його позитивному значенні можна розглядати як міру внеску нецентральних сил у загальне напруження, що діє в зразкові. Тож виходячи із даних таблиці можна стверджувати, що обробка фіброїнових волокон лужним розчином збільшує той внесок у напруження, який пов'язаний $з$ нецентральними силами. Нецентральність сил, у свою чергу, є наслідком орієнтації ланцюгів вздовж волокна.

Виявлений факт збільшення значень модуля третього порядку під час обробки волокна лужним розчином свідчить про те, що в невпорядкованих областях при цьому зростає орієнтація ланцюгів уздовж осі волокна. Виходячи із цих міркувань, можна, на нашу думку, стверджувати, що деформаційну поведінку невпорядкованих областей при дії лужного розчину визначають два фактори: з одного боку - обробка лужним розчином збільшує дефектність невпорядкованих областей, що приводить до зменшення модуля другого порядку; але, водночас, поряд із збільшенням кількості дефектів, відбувається орієнтація

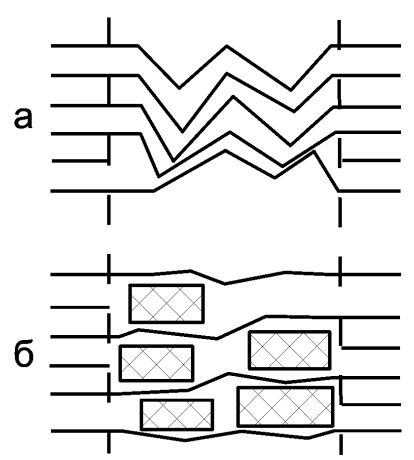

Рис. 3. Модель структури невпорядкованих областей: $a$ - до обробки, б - після обробки волокна лужним розчином

ланцюгів, яка проявляється у тому, що кути повороту віртуальних в'язей наближаються до тих значень, які відповідають розташуванню цих в'язей у площині зигзага. Усі попередні міркування проілюстровано на рис. 3.

Як видно з цього рисунка, ланцюги зображено у вигляді ламаних, де кожен відрізок відповідає певному віртуальному зв'язку. На рис. $3, a$, де зображено структуру необробленого волокна, нахили цих відрізків до осі волокна більші, ніж нахили аналогічних відрізків на рис. 3,б, що відповідає обробленому волокну. Крім того, на рис. 3,б зображено, у відповідності із попередніми міркуваннями, пустоти - затоновані ділянки рисунка.

\section{5. Висновки}

Обробка фіброїнового волокна лужним розчином приводить до таких структурних змін:

1. У невпорядкованих областях з'являються дефекти - порожнини між фіброїновими ланцюгами.

2. Ланцюги у невпорядкованих областях, віртуальні зв'язки яких у необробленому стані суттєво відхилялись від осі волокна, орієнтуються, що проявляється в зменшенні кута нахилу віртуальних зв'язків до осі волокна.

1. Ullmann's Fibers (John Wiley and Sons Ltd, 2002).

2. Protein-Based Materials, edited by D. Kaplan and K. McGrath (Birkhaeuser, Boston, 1996).

3. V. Kearns, A.C. MacIntosh, A. Crawford, and P.V. Hatton, in Topics in Tissue Engineering, Vol. 4, edited by N. Ashammakhi, R. Reis, and F. Chiellini (2008), Chapter 1.

4. Ю.С. Голик, Ю.Ф. Забашта, В.Н. Махровский, Акуст. журн. 3, 543 (1992). 
5. Л.А. Булавин, Ю.Ф. Забашта, Фізична механіка полімерів (Київський університет, Київ, 1999).

6. J.O. Warwicker, Acta Crystallogr. 7, 565, (1954).

7. Л.А. Булавин, Ю.Ф. Забашта, О.С. Свєчнікова Фізика полімерів (Київський університет, Київ, 2004).

8. С.Я. Френкель в кн.: Ф.Х. Джейл, Полимерные монокристалль (Химия, Ленинград, 1968).

9. K. Nakamae, T. Nishino, and H. Ohkubo, Polymer J. 30, 1243 (1989).

10. K. Lucas, J.T.B. Shaw, and S.G. Smith, Biochem. J. 83, 164 (1962).

11. S. Xiao, W. Stacklies, M. Cetinkaya, B. Markert, and F. Graeter, Biophys. J. 96, 3997 (2009).

12. P.J. Flory, Principles of Polymer Chemistry (Cornell Univ., Ithaca, NY, 1953).

Одержано 03.01.12

СТРУКТУРНЫЕ ИЗМЕНЕНИЯ В ФИБРОИНОВОМ ВОЛОКНЕ ПОД ДЕЙСТВИЕМ ЩЕЛОЧНОГО РАСТВОРА

Л.А. Булавин, Ю.Ф. Забашта, А.В. Каспрова,

С.П. Сенчуров, О.С. Свечникова

$\mathrm{P}$ е $з$ ю м е

Проведено сравнительное исследование акустических свойств фиброиновых волокон, обработанных и необработанных щелочным раствором. Получены зависимости скорости звука от ста- тического напряжения, растягивающего волокно. По этим зависимостям рассчитаны значения модулей упругости второго и третьего порядков. На основе полученных значений сделаны выводы об изменениях структуры, которые происходят в фиброиновом волокне при обработке его щелочным раствором, а именно установлено, что обработка приводит к появлению дефектов типа пустот в неупорядоченных областях и ориентации цепей в этих областях вдоль оси волокна.

\section{STRUCTURAL CHANGES IN A FIBROIN FIBER INDUCED BY AN ALKALINE SOLUTION}

L.A. Bulavin, Yu.F. Zabashta, A.V. Kasprova, S.P. Senchurov, O.S. Svechnikova

Taras Shevchenko National University of Kyiv, Faculty of Physics

(64, Volodymyrs'ka Str., Kyiv 01601, Ukraine)

$\mathrm{S}$ u $\mathrm{m}$ m a r y

A comparative study of acoustic properties of fibroin fibers treated and untreated in an alkaline solution has been carried out. The dependence of the sound velocity on the static tensile stress in a fiber is determined and is used to calculate the elastic moduli of the second and third orders. A conclusion is made that the treatment of a fibroin fiber in the alkaline solution modifies its structure; in particular, in the course of the treatment, there emerge defects (voids) in unordered areas, and the chains become oriented along the fiber axis in those areas. 